\title{
》BERI SKRBNU DOBRE BUKVE, DE TI POSTANEŠ VUČEN, MODER INU BRUMEN ... BUG TEBI DODELI DUHA TE MODROSTI, PEJDI, ŽIVI INU JIMY SE DOBRU ...« JAN AMOS KOMENSKÝ IN NJEGOVA DELA PRI SLOVENCIH: RECEPCIJA V 19. STOLETJU
}

Po 6. aprilu 1941 si je pomemben del slovenskega narodnega ozemlja prigrabila fašistična Italija. In tako so po okupaciji Ljubljane blagodati »izboljševanja slovanskih tujerodcev s tisočletno italijansko kulturo" na vzhodu novega rimskega imperija, kot se je tedaj mislilo in govorilo, doletele ne le ljudi, temveč tudi topografske entitete in njihova poimenovanja. - Kot preimenovanja: slovensko in slovansko se je moralo umakniti italijanskemu. Proti temu ni pomagalo ne kranjsko kolaboriranje $\mathrm{z}$ italijansko oblastjo, celo romanje $\mathrm{v}$ Rim $\mathrm{k} d u c e j u$ in bolj ali manj ponižne, celo klečeplazne lojalnostne geste vrhov slovenske konservativne politike ne. Na italijanski strani ni bilo popuščanja: tudi ulice in njihova dotedanja obeležja v glavnem mestu Ljubljanske pokrajine so morali izražati novi red. Ena od takih pridobitev je bila tudi nova Petrarcova ulica, ki pa ni bila nič drugega kot stara Komenskega ulica.

Ta del mesta je namreč 5. aprila 1892, ob tristoletnici rojstva (Valenčič 1989, 108), na pobudo slovenskih šolnikov' dobil ime po zadnjem češko-

1 Sklep o poimenovanju Ulice Komenskega je sprejel ljubljanski mestni zastop leta 1892; hkrati je isti organ učiteljskemu društvu odobril tudi 100 goldinarjev za pripravo slavnostnega večera v počastitev Komenskega. 
bratskem škofu, prevajalcu, uredniku, pisatelju, teologu, filozofu in pedagogu, ki je v svojem času in kasneje slovel kot pred njim že Philipp Melanchthon - kot praeceptor Europae - Janu Amosu Komenskem (1592-1670).

Kajpak tristoletnica rojstva Komenskega ni točka o recepcije spisov znamenitega češkega reformiranega duhovnika med Slovenci. Prvi tekst Komenskega, ki je izpričano zbudil pozornost v jezikovno slovenski učeni kulturi, je bil namreč učbenik Orbis pictus, Svet v podobah (tudi Orbis sensualium pictus). Prva izdaja je luč sveta zgledala 1658. v Nürnbergu in je bila latinsko-nemško dvojezična. Za njo je delo izšlo še v številnih drugih natisih, 1666. prvič tudi štirijezično (latinščina, nemščina, italijanščina in francoščina), med založniki pa je bila tudi znamenita amsterdamska založniška in knjigotrška hiša Elzevir (1673).

Omenjeno knjigo se občasno označuje kot prvo slikanico za otroke na svetu ali celo kot prvo otroško slikovno enciklopedijo, kajti dvo- ali večjezični slovar je bil v več kot 150 razdelkih povsod opremljen s slikami entitet, ki so jih izrazi označevali, Komenský pa je v knjigi praktično prikazal, kako si predstavlja svoj pedagoški koncept schola ludus (šola skozi igro) in kako naj preko zaznave s čutili poteka učenje jezika/slovarja. Ni ugotovljeno, katera dvojezična latinsko-nemška izdaja je bila uporabljena, toda ni dvoma, da je izrazje Komenskega, seveda brez slikovnih ponazoril, iz Orbis pictus našlo pot v trijezični slovar Dictionarium trilingue v dveh delih, ki ga je spisal kapucin Janez Adam Gaiger, z redovnim imenom Hipolit Novomeški (1667-1722). Slovar, ki ga je avtor končal 18. aprila 1712, je sicer ostal v rokopisu, razen naslovne strani iz leta 1711 in poskusne strani pri črkah A in B, ki sta bili izdelani pri ljubljanskem tiskarju Johannu Georgu Mayru in sta se ohranili kot edini tiskani del omenjenega leksikografskega dela. Komenský je v Hipolitovem latinsko-nemško-slovenskem in nemško-slovensko-latinskem slovarju zastopan med drugim tudi s posameznimi terminologijami, npr. $\mathrm{z}$ astronomskim izrazoslovjem: poleg temeljnih latinskih in nemških astronomskih terminov so zapisani slovenski izrazi. V zvezi $s$ to prvo recepcijo Komenskega pri Slovencih je literarnozgodovinska znanost ugotovila: 
Za Hipolita je nesporno, da se je z miselnostjo dela Komenskega popolnoma strinjal. Razčlenitev sestavin te miselnosti pa dokazuje, da gre za idejni koncept, ki ga je Hipolit hotel uveljaviti na Slovenskem. Misli, ki so bile stičišče, so najbolj jasno izražene v Sklepu [poudarjeno v izvirniku]. Otrok, ki je dojemal predmetni svet po tem delu [Komenskega Orbis pictus v njegovi slovenski prevodni transformaciji pri Hipolitu; prevod so teoretiki v 18. stoletju šteli ne le za pomembno, temveč tudi za književno izvirno delo; op. J. V.], je spoznal »vse reči, katere se morejo izkazati«, ter se naučil latinsko, nemško in slovensko. Poudarek na izkustveni splošnosti izobrazbe je bil nov v primeri s prakso jezuitskih šol. Pri Komenskem je izraz pansofističnega [verjetno je bilo mišljeno pansofičnega, kajti v opusu Komenskega ni najti nič takega, kar bi bilo poimenovano s pansofizem ipd., je pa ves čas govora o pansofiji, op. J. V.] hotenja, v katerem se je izražala želja sproščenega individua po spoznavanju objektivnega sveta. Kot takega ga je sprejel Hipolit, ki je v besednjaku upošteval tudi pojme iz narave in v zametku podal slovensko znanstveno terminologijo. Zato je razumljivo, da se je strinjal tudi z besedami: »Pojdi naprej, inu beri skerbnu druge dobre bukve, de ti postaneš vučen, moder inu brumen ... Bug tebi dodeli duha te modrosti, pejdi, živi, inu jimy se dobru.« (Pogačnik 1968, 193)

Ta neutesnjena poustvarjalna recepcija Komenskega pri Hipolitu meče, kot je misliti, pomenljivo luč tudi na njegovo in kasnejšo dobo srednjeevropskega katoliškega baroka v Notranji Avstriji, na Kranjskem, in, predvsem, na njeno historiografsko ubeseditev. Zavoljo karakterno izrazitih, občasno celo silovitih osebnosti, ki so oblikovale ta čas in prostor, včasih pa tudi zaradi intence historiografa v tukajšnji zgodovinski paralelogram silnic volje, moči, pozicij in pomenov "položiti« kaj, kar je komajda razbrati iz tedaj nastalih primarnih virov, se more namreč dogoditi, da so podobe osebnosti, časa in njegovih mentalitet očrtane precej bolj ostro in enoznačno, robovi miselnih horizontov pa opredeljeni znatno bolj enoznačno, kot bi jim sicer pritikalo. Misliti je namreč, da Komenský za Hipolita poleg jezikovno konceptualne privlačnosti ni bil nesprejemljiv vsaj zavoljo naslednjih zgodovinskih dejstev: a) Orbis pictus ni bil počaščen z umestitvijo na Index librorum prohibitorum, b) Komenský kot češki brat in verski izgnanec iz Češkega 
kraljestva ni bil slaba vest rekatolizatorjev na Kranjskem in ga tako, podobno kot Pavla Stránskega, Ondřeja Habervešla in številne druge, ${ }^{2}$ ni zadel tekstni damnatio memoriae v kranjski deželni zavesti in njeni historiografiji, temveč v češki, c) od začetka tridesetletne vojne je minilo skoraj tri četrt stoletja in d) prva desetletja 18. stoletja so v evropski kulturi tudi v katoliškem delu že obdobje, ko se začne vsaj deloma obnavljati koncept bolj ali manj splošne komunikacije $\mathrm{v}$ »učeni republiki«, vsaj skozi participiranje v učenih akademijah. Primerljiv postop - recepcija skozi poročanje, ne aktualistično apelativno versko opredeljevanje - je najti npr. v Valvasorjevi epohalni Slavi Vojvodine Kranjske v zvezi s protestantizmom na Kranjskem.

Slovenska pedagoška zgodovina je recepcijo Komenskega doslej tradicionalno členila le $\mathrm{v}$ dvoje obdobij in ugotavlja kot tipološko značilnost prvega prevajanje oziroma predelavo Komenskega filološko-pedagoških spisov v slovenski jezik in topogledno krepitev slovarja slovenskega jezika, v drugem obdobju pa najdeva kot ključno seznanjanje Slovencev s pedagoškimi in deloma filozofskimi nazori Komenskega (Medveš 1997, 67).

Toda za sodobno historiografsko obravnavo recepcije Komenskega med Slovenci se zdi, da taka posplošitev ne zadošča več. Zato velja zagotovo upoštevati vsaj še naslednje: a) splošna recepcija Komenskega kot pedagoga in filozofa, ne pa kot teologa, se prične $z$ objavo prevodov in refleksivnih zapisov o njem $\mathrm{v}$ široko dostopni slovenski pedagoški periodiki zadnje tretjine 19. stoletja (Učiteljski tovariš, prva objava o

2 Primarni vir Clavis haeresim claudens et aperiens - Klič kacírské bludy k rozeznávání otvírající, $k$ vykořenění zamykající (1729) patra Matěja Antonína Koniáša razkrije, da je bil tudi Komenský med 1233 knjižnimi naslovi v latinskem, nemškem, francoskem in, prvenstveno, češkem jeziku, ki jih je vneti češki apostol predajal ognju, toda ne ves njegov opus, temveč pretežno tiste knjige, ki so bile na Češkem in Moravskem dosegljive v prvi tretjini 18. stoletja, ker so preživele ujme tridesetletne vojne ali pa so $\mathrm{v}$ dežele sv. Václava prišle tajno takrat ali kasneje. Recepcije Komenskega na Kranjskem ni določalo nič podobnega kot Klíč in protireformacijske komisije, ki so njegove in druge proskribirane knjige po Češkem in Moravskem sledile, plenile in sežigale celo še do maja 1781 (!); cesar Jožef II. je oktobra istega leta podpisal tolerančni patent in tako ustavil tudi tovrstno versko preganjanje v deželah sv. Václava (1781; Vinkler 2010, 85). 
Komenskem 1871; Popotnik, prva objava 1885$),{ }^{3}$ ne prej, 2) mesto objave spisov Komenskega glede na idejne meridiane publikacije, urednikov in avtorjev besedil o Komenskem definira horizont pričakovanja splošnega slovenskega bralca in bralca-poznavalca. Slednje posebej izrazito razkriva spor o Komenskem, ki se je ob tristoti obletnici njegovega rojstva (1892) razvnel med slovenskimi pedagogi in katoliškim teologom Antonom Mahničem.

Navdušenje nad Komenským med liberalnejšim delom slovenskega učiteljstva, ki je pisalo zlasti v Popotnika, bilo pobudnik in organizator slovesnosti ob tristoletnici znamenitega Čeha v Ljubljani in tudi poimenovanja ljubljanske ulice po njem, je namreč pri odločno katoliško integralističnem ter strogem arbitru vseh družbenih pojavov v tedanjem slovenskem prostoru izzvalo sicer, kot vedno, argumentacijsko artikuliran in slogovno izbrušen, toda izrazito negativen odziv katoliške strani na Komenskega med Slovenci.

Izpod Mahničevega peresa sta tako leta $1892 \mathrm{v}$ Rimskem katoliku, ki ga je goriški profesor teologije tudi urejal, prišli dva polemična eseja, in sicer Internacijonalna slavnost Jana Amosa Komenskega in Bodi luč! slaviteljem Komenskega!, analiza obeh besedil pa pokaže pomenljivo tipološko podobnost $\mathrm{z}$ Mahničevim ocenjevanjem sodobne in polpretekle slovenske književnosti, pa tudi s sporom okoli Trubarja v istem obdobju. Zdi se, da je služil Komenský Mahniču predvsem kot priročna prigodniška odskočna deska za razčiščevanje idearijev, ki so imeli takrat le od daleč in komajda še opraviti s Komenským. Mahnič je namreč obletnico Komenskega uporabil za komuniciranje ideje, kakšna naj bi bila po njegovem ustrezna pedagogika in šola njegove dobe. Spoprijem okoli Komenskega je bil tako idejni obračun o tem, ali naj bodo slovenski šolniki posredniki starejših humanističnih, toda ne nujno katoliških, in sodobnih liberalnejših pogledov na šolo in šolanje ali pa naj

3 Hipolitovega prevoda Orbis pictus zato ni mogoče šteti med recepcijsko množično odmevna besedila, kajti splošni publiki postane besedilo znano šele v objavi Ivana Laha v Popotniku (1916-1919), deli besedila pa znatno prej: najprej pri Valentinu Vodniku in nato pri Blažu Potočniku, kjer pa Komenskega besedilo opravlja funkcijo širitve besedišča slovenskega jezika (Walter 2002). 
bo šola dal integralističnega družbenega modela, poglavitni del tedaj dobro uglašenega tria (služeča) šola - (rimskokatoliška) štola - (habsburška) pištola; ta je na vrh vsega bivajočega stavil Boga v ekskluzivno rimskokatoliškem razumevanju, pod njim Rimsko cerkev z njeno dogmatiko, moralko, $\mathrm{z}$ njeno nepremenljivostjo ter $\mathrm{z}$ dozdevno nezmotljivo učiteljsko avtoriteto, $\mathrm{z}$ roko $\mathrm{v}$ roki s habsburškim cesarskim prestolom, povsem spodaj pa bolj ali manj nesamostojne oziroma podrejene družbene podsisteme. - Tudi šolstvo. In šolnike.

»Na drugi strani mize« so stali Mahniču nasproti sodelavci mariborskega nadučitelja Mihe Nerata pri Popotniku, ki je prvič prišel v svet 10. januarja 1880. Poleg Nerata so ga v Celju ustanovili liberalni Štajerci Anton Brezovnik, učitelj iz Vojnika, vodja celjske okoličanske osnovne šole Janko Lopan in poslanec $\mathrm{v}$ štajerskem deželnem zboru (1878-90) Mihael Žolgar, sicer gimnazijski profesor in kasneje tudi šolski nadzornik. Popotnik je nastal zavoljo potrebe liberalnejšega dela slovenskega učiteljstva, ki na začetku osemdesetih let 19. stoletja ni imelo primernega objavljanega organa, s katerim bi se identificiralo: Slovenski učitelj (1872-77), ki ga je izdajal Ivan Lapajne, je, kot je zapisal izdajatelj, prenehal izhajati, ker »imamo Slovenci za obilo svojih časopisov premalo materialnih sredstev« (Lapajne 1877, 356). List je imel na vratu zaplembe posameznih številk, tiskovne tožbe, v katerih ga je občasno zastopal celjski odvetnik in »rodoljub z dežele« dr. Josip Sernec, in to brezplačno, veliko naročnikov, a malo plačnikov in zato dolgove v tiskarni, predvsem pa so umanjkali situirani in vplivi podporniki. Slovenski učitelj je v razdelku Šolske novice in drobtine utemeljil, zakaj zapira vrata:

Še drugi razlog temu, da s svojim delovanjem prenehamo, je ta, da piha sedaj tako mrzel in suh veter za slovenske liste, slovenske knjige, da se mora vse posušiti in zmrzniti, kar ne dobiva dovolj moči in moče. No, možje pa, kateri so bili glavni podporniki listu, so vsled teh okoliščin prišli v zadrege, v neprilike in tudi materialno škodo tako, da jim vsaj za zdaj 
ni mogoče ovijati se v plašč svojega domoljublja in braniti se mrzlemu, sušilnemu severnemu vetru ... ${ }^{4}$ (Lapajne 1877, 357)

Zdi se, da je imel Lapajne v mislih za slovensko časopisje in narodnostno vprašanje nič kaj zavidljivo situacijo pod "meščanskim ministrstvom« Karla kneza Auersperga; po prenehanju Slovenskega učitelja so imeli slovenski pedagogi pri roki le Učiteljskega tovariša, ki je bil znatno konservativnejšega idearija kot Slovenski učitelj, toda od 1880 naprej tudi Popotnika. Ta si je zastavil naslednji program:

Predvsem bo skrbel, da bo vsekdar vedel o važnih in potrebnih rečeh kako modro besede temeljito, pa po domače povedati: opazoval bo marljive učitelje, kako se $\mathrm{z}$ najboljšim uspehom pri pouku mladine trudijo, da jih lahko drugim v posnemanje priporoči; poslušal bo dalje pravljice in pripovedke, katere si preprosto ljudstvo pripoveduje, kakšne pesmi si prepeva ali kake navade in šege se pri njem na raznih krajih nahajajo ... Poizvedoval bo, kje je kak pokojnik kaj imenitnega in slavnega $v$ blagor človeštva storil [poudaril J. V.] ... (Popotnik 189o, št. 3, 1)

Popotnika je kot drugi urednik od 1883. celih 36 let vodil Miha Nerat, časopis je izhajal najprej v Celju in nato v Mariboru, imel številne stalne sodelavce, ki so bili pripravljeni podobno kot Nerat - in številni pred in po njem, tudi danes! - pisati na etični pogon in za boglonaj, med njimi tudi pesnika Josipa Frauensfelda, znanega štajerskega rodoljuba, ki je svoj strokovni moto izpovedal s stavkom: »Za Slovence mora biti občevalni jezik slovenski, drugače sploh nehamo biti Slovenci.« (Hojan 2003, 333.)

Recepcijsko povsem drugačno "specifično težo « kot na začetku izhajanja pa je Popotnik dobil leta 1889, ko ga je za društveni časopis sprejela Z(a)veza slovenskih učiteljskih društev, tedaj poglavitna organizacija slovenskega učiteljstva. Le-ta je leta 1890 Popotnika prevzela v last tudi kot lastnica in izdajateljica, kar je dalo časopisu status uradne sta-

4 Zaradi lažjega branja navajam navedke iz primarnih virov 19. stoletja v pričujoči razpravi v pravopisno posodobljeni obliki, in sicer vse navedke v razpravi brez izjeme. 
novske periodike $e^{5}$ in tako so miselne smeri, razvidne iz revije, postale do določene mere tudi programske smernice.

In o slednjem - kakšen program in smer, liberalna ali konservativna, samostojna ali katoliško integralistična, naj oblikujeta šolo za slovenske duše - se je zdelo Antonu Mahniču še kako pomembno razpravljati tudi ob tristoletnici znamenitega češkega humanista.

\section{"In ker se 'kristjan' istoveti s 'človekom' - evo vam v Komenskega nazorih seme poznejšega socijalizma in komunizma«: Komenský v očeh Antona Mahniča}

Mahnič se je s Komenským v jubilejnem letu češkega učenjaka ukvarjal v dveh polemičnih esejih $\mathrm{z}$ naslovi Internacijonalna slavnost Jana Amosa Komenskega in Bodi luč! - slaviteljem Komenskega!. Oba sta izšla v Rimskem katoliku, prvi spomladi 1892 kot odziv na tretjo številko Popotnika (10. februarja 1892) in drugi kot končni katoliški censeo na slovensko prigodniško recepcijo Komenskega v Popotniku in Učiteljskem tovarišu, ki je, kot je razbrati iz zapisanega besedilja, želela prerasti tudi $\mathrm{v}$ trajnejše miselno op(l)ajanje slovenskega učiteljstva s koncepti in pogledi znamenitega Čeha.

$5 \mathrm{~V}$ programskem uvodu uredništva in "upravništva« revije v prvo številko Popolnika 1890 (Popotnik 189o, št. 3, 1-3) so tako zapisali, kot je misliti, zelo pretehtano programsko smernico, v kateri so poleg lojalistične vdanostne geste tedanjemu oblastnemu primatu države nad šolo izpovedali tudi lastno, nacionalno-liberalno smer:

»Prepirov [Popotnik] nikdar ne bode iskal, odločno pa bode pobijal krive nazore, kakor da je šola polje brez gospodarja, na katerem sme delati vsakdo svoje gospodarske [upravne, dodal J. V.] poskuse. Hodil bode vedno svojo ravno pot ne glede na to, če se tudi pojedincem zameri; pod geslom: »Vse za vero, dom, cesarja!« bode delal to, da dosežemo svoj cilj, ki se nam svita sicer še v veliki daljavi, a vendar postaja vedno razločnejši, namreč da pridobimo »Šolo - narodu, šolo - učiteljstvu [poudaril J. V]!« 


\section{Recepcija Komenskega v Popotniku in Učiteljskem tovarišu}

\section{Popotnik (1892)}

Prvi recepcijski impulz v slovenskem letu Komenskega je bilo poročilo o novem kipu Jana Amosa Komenskega iz delavnice slikarja Jana Rypote (1843-1914) in kiparja Františka Heidelberga (1844-1919) v Pragi (Popotnik 1892, št. 2, 32), sledilo pa je besedilo, ki je izhodiščna točka recepcije Komenskega na Slovenskem v letu 1892. V tretji številki Popotnika je namreč 1o. februarja 1892 prišel iz tiskarne prigodniški članek z naslovom Tristoletnica rojstva J. A. Komenskega, ki ga je podpisal R. K. in se pri tem označil za »vnetega čestilca Komenskega». Besedilo je povečini poročevalsko, in sicer slovenskega bralca seznanja s pripravljanimi slovesnostmi in dejavnostmi v počastitev Komenskega na Češkem, Moravskem in drugje po Evropi: obširno evidentira ustanove, kraje, pripravljane slovesnosti, odprtja, med drugim tudi odprtje Muzeja Komenskega (danes Státní pedagogické muzeum v Praze) v Pragi, nove umetniške upodobitve Komenskega, pa seveda sveže knjižne izdaje, ki ponavadi spremljajo velike obletnice zaslužnežev. Toda poleg zapisanega so pomenljivejši naslednji izvirni predlogi:

Mi, slovenski učitelji, ki smo se čutili dovolj močne združiti se v jedno celoto za jačanje svojega stanu in poklica, smo gotovo tudi idealno in moralno zmožni z lepšimi izsledki oslaviti slavnega Komenskega; zato se usojam slovenskemu učiteljstvu v blagohotno pretresovanje in uvaževanje staviti sledeče predloge:

Predlog I. Učiteljstvo slovensko naj slavi tristoletnico Komenskega:

a) Vsako učiteljsko društvo zase po svojih močeh in razmerah v svojem okraji s prirejevanjem slavnostnega zborovanja, petjem oziroma koncertom in s poljudnim prednašanjem [predavanjem, dodal J. V.].

b) Zaveza slovenskih učiteljskih društev pa o priliki svojega zborovanja o binkoštih v skupnej svečanosti. [...] 
Predlog II. V vedni [večni] spomin Komensky-jev naj si Zaveza in vsa ostala slovenska učiteljska društva pridenejo pridevek »Komensky" [poudaril J. V.] ... (Popotnik 189o, št. 3, 34, 35)

Pisec svoje besedilo zaključuje:

Naj ne bode nikogar, kateri bi se letos z dostojnim češčenjem [poudaril J. V.] ne spominjal Komenskega nesmrtnih zaslug ... (Popotnik 189o, št. 3,36 )

Vrh recepcije Komenskega v tej številki Popotnika zagotovo predstavlja objava štiriglasnega moškega zbora $\mathrm{Ob}$ rojstveni 300 -letnici Jana Amosa Komenskega (Zveneli so meči) (Popotnik 1890, št. 3, nepaginirana priloga): pesemsko besedilo je napisal Fran Gestrin (1865-1893), glasba pa je privrela izpod peresa člana znamenite dinastije zdravnikov in skladateljev iz Sv. Jurija ob Južni železnici - »rodoljuba z dežele« Gustava Ipavca. Omenjeni moški zbor je doživel premiero na eni od slavnosti v čast Komenskega, ${ }^{6}$ najverjetneje 26 . marca v Ljubljani, zagotovo pa so ga izvedli tudi 7. aprila 1892 v Mariboru, na slavnostni bésedi Ljubljanske čitalnice, na »večeru Komenskega», ki jo je kot osrednji dogodek v počastitev češkega učenjaka 19. aprila 1892 priredila Zveza slovenskih učiteljskih društev, pa tudi na slovesnosti v počastitev Komenskega 5. maja v Sežani in 2. junija 1892 na letnem zboru Zveze slovenskih učiteljskih društev v Kranju.

$\mathrm{V}$ četrti in peti številki Popotnika nato sledijo redne informacije o slavnostih Komenskega po svetu, jedro poustvarjalne recepcije Komenskega pri Popotniku pa predstavlja šesta številka, ki je bila objavljena 25. marca 1892 - tri dni pred veliko obletnico in dan pred prvo slovesnostjo v počastitev Komenskega $\mathrm{v}$ Ljubljani - in je v celoti posvečena Komenskemu. Prinaša prevod kratke biografije Komenskega izpod peresa češkega šolnika, arheologa in zgodovinarja Jana Karla Hrašeja (18401907). Ob njem je še izvleček iz Komenskega pedagoških del s povzetkom njegovih temeljnih konceptov o učiteljih, učencih in šoli (gre za prired-

6 Ljubljana: 26. marec, 9. in 19. april; Šmarje pri Jelšah: 27. marec; Maribor: 7. april; Sežana: 5. maj. 
JONATAN VINKLER

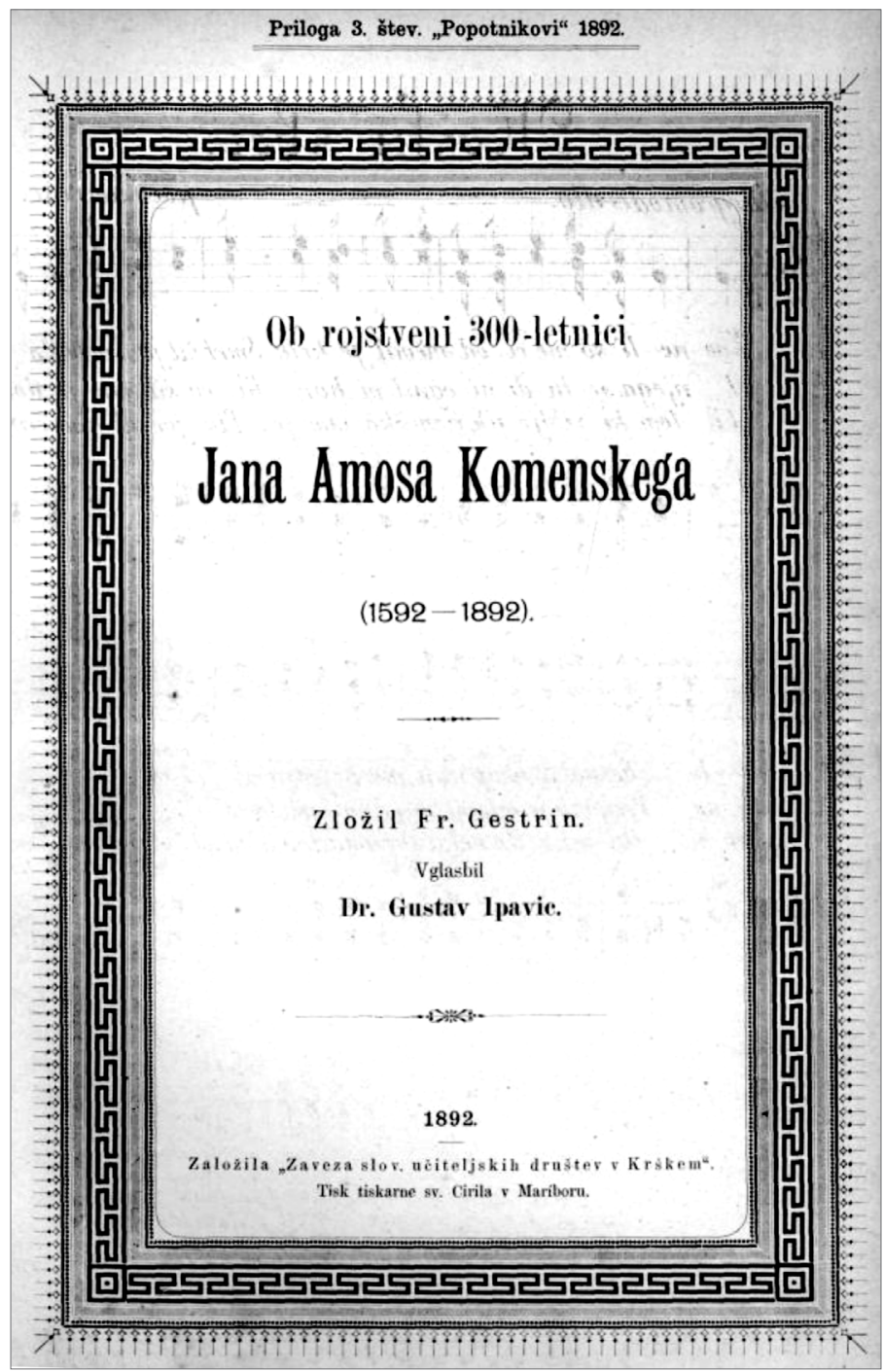

Zbor Gustava Ipavca, skomponiran v čast tristoletnice rojstva Jana Amosa Komenskega. 


\section{Mrooki sbor.}
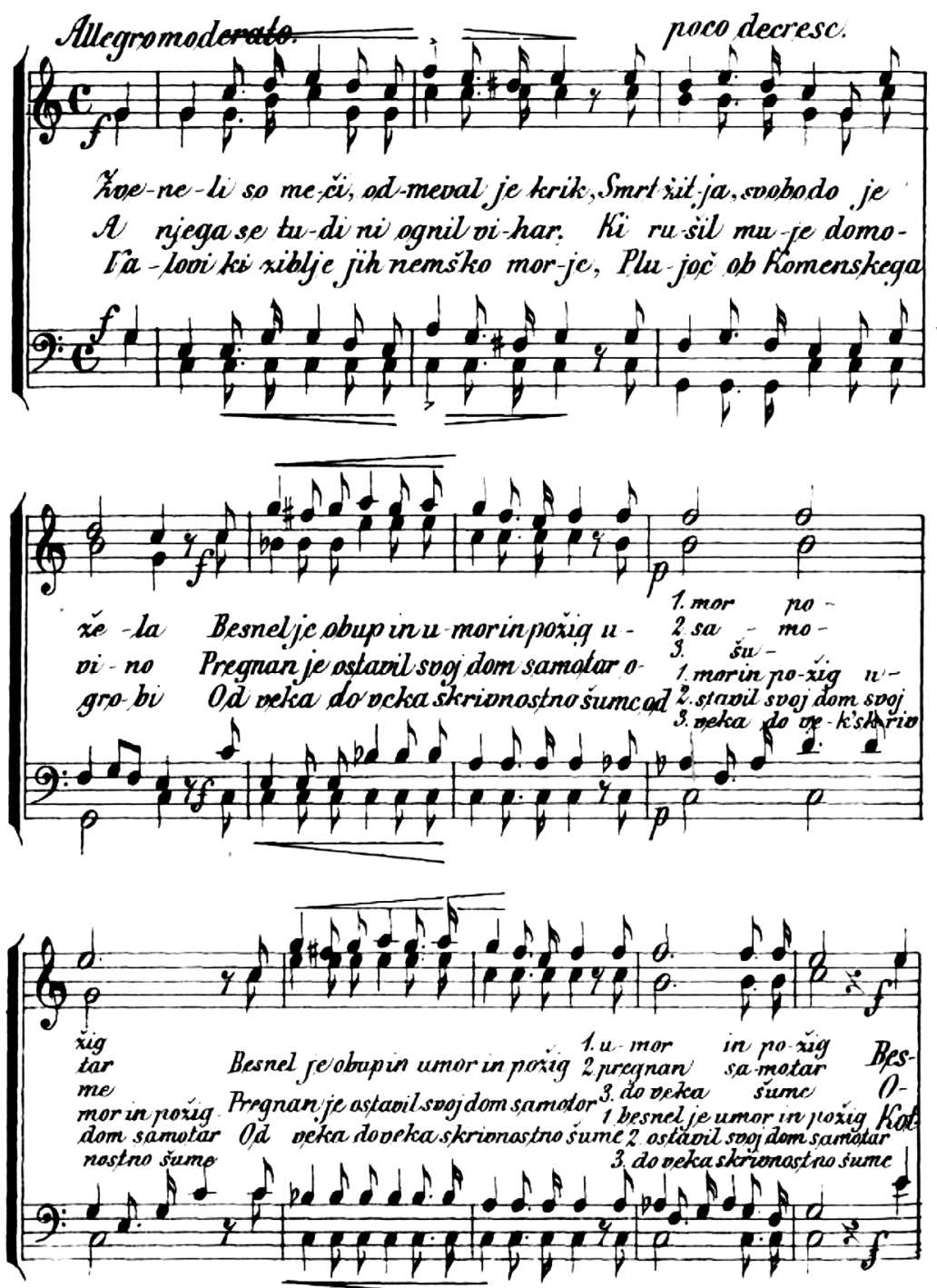


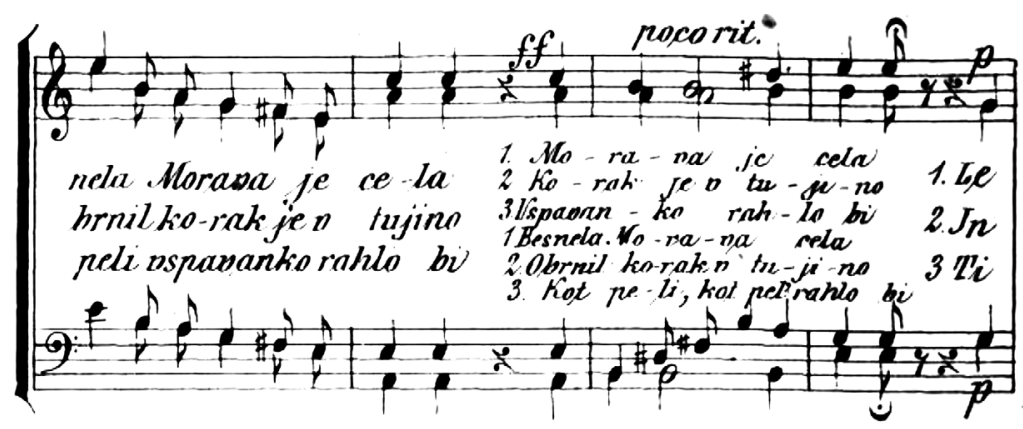

pocominomosso stringendo molto crescendo
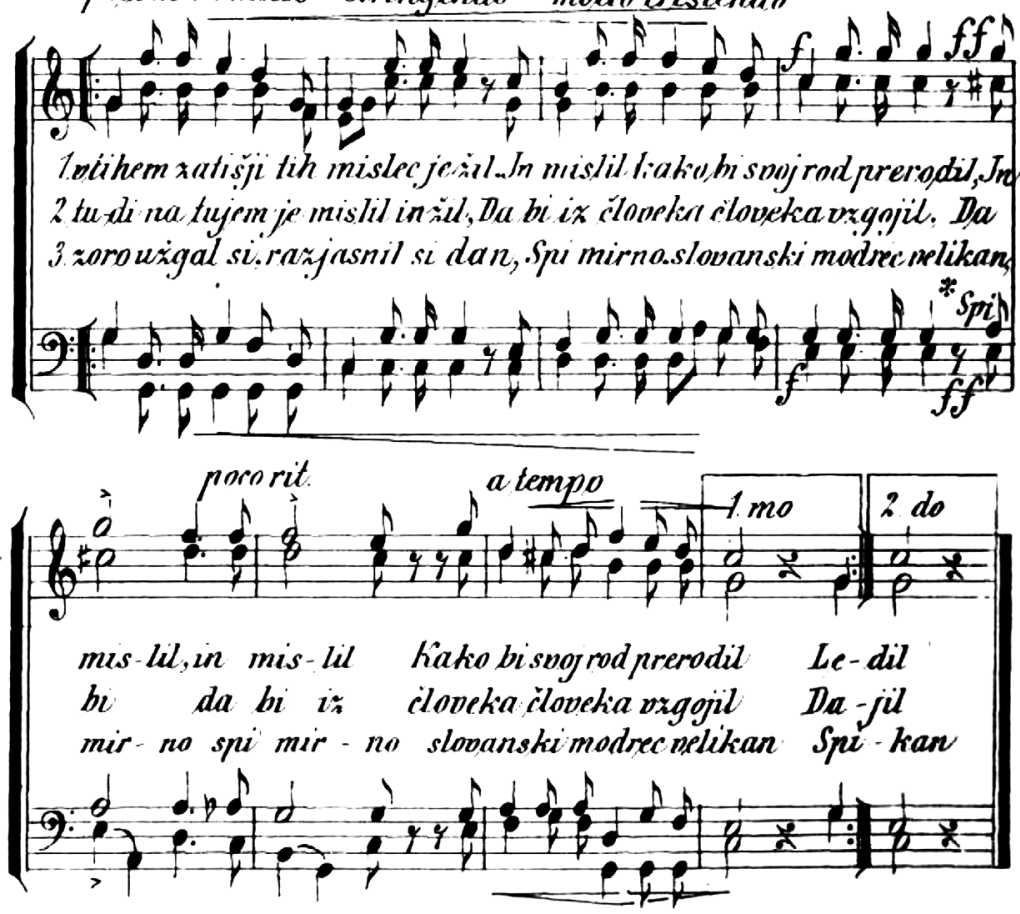

*) hadnja nrsta..spi mirno" porasi in p-slowanski modrec melikan" sopet pocostringendo. 
bo češkega izvirnika), vrh izdaje pa zagotovo predstavlja cikel treh pesmi Tri noči (Ob Komenskega tristoletnici) Frana Gestrina.

Sedma in osma številka Popotnika prinašata verjetno prvo sodobno slovensko razpravno besedilo o pedagogiki Komenskega, J. A. Komenský, njegov avtor je bil Henrik Schreiner (1850-1920), nato pa si od devete do petnajste številke (10. avgusta 1892) sledijo poročila o proslavah v tujini, zabeležke o recepciji na proslavah pri nas, toda tudi knjižne recenzije najnovejših spisov o Komenskem. Med njimi je tudi poročilo o Gustva Adolfa Lindnerja (1828-1887) biografiji Johann Amos Comenius, sein Leben und Wirken, ki je na Dunaju in v Leipzigu izšla v jubilejnem letu Komenskega. Besedilje o Komenskem je torej v Popotniku skoncentirirano na prvih osem mesecev 1892., ko so se na Češkem in drugje po Evropi okoli tristoletnice rojstnega dneva Komenskega zgostili tudi slavilni dogodki, nato podobnih objav ni več najti, Popotnik pa se h Komenskemu vrne čez več kot dve desetletji, 1916., sredi viharjev prve svetovne vojne, ko začne po delih objavljati Hipolitov prevod Orbis pictus v slovenščino. - Ideja, da se slovenska učiteljska društva poimenujejo po klasiku pedagogike, se kajpak ni uresničila, je pa, kot bo razvidno v nadaljevanju, vzbudila veliko žolčne jeze pri »blaženem Antonu od Kala«, kot je leto poprej (1891) v romanu 4000 Mahniča ne brez jedke ironije poimenoval Ivan Tavčar.

\section{Učiteljski tovariš (1892)}

Učiteljsko glasilo s podobo Antona Martina Slomška na naslovni strani - ob slednje se Mahnič ni pozabil obregniti in časopisu poočitati, da je njegovo populariziranje Komenskega menda kaj malo skladno s Slomškovim »duhom« - je v jubilejnem letu namenilo Komenskemu občutno manj pozornosti kot Popotnik. To je razumljivo, kajti mentalno obzorje Učiteljskega tovariša, ki ga je izdajal nadučitelj in c.-kr. šolski nadzornik Andrej Žumer (1847-1903), je bilo vendarle pomaknjeno nekoliko bolj proti takrat tradicional(istič)nemu razumevanju šole in šolnikov, kot je to mogoče s primerjavo konceptov ugotoviti za Popotnika. Toda kljub vsemu je v Učiteljskem tovarišu izšlo šest objav, ki zadevajo neposredno Komenskega in njegov jubilej. 
Med besediljem je tako najti »vestnik o Komenskem«, v katerem Učiteljski tovariš poroča o krajih jubilejnih dogodkov na Češkem in drugje po Evropi ter o dogodkih samih. Prinaša, kot se zdi, tudi prvo daljšo biografijo Komenskega, in sicer gre za izvirno, ne prevedeno razpravo. Spisal jo je učitelj in glasbenik Jernej Ravnikar (1856-1920), ki se je kasneje eksponiral tudi kot deželnozborski poslanec na listi Slovenske ljudske stranke (1907-1913). Ravnikarjev Jan Amos Komenski (V spomin tristoletnice) je izšel v petih številkah Učiteljskega tovariša med 1. februarjem 1. aprilom 1892, Ravnikar pa se je leto kasneje podpisal tudi pod prvi prevod Komenskega Didaktike (1893, Pedagoška knjižnica, 1. zvezek) v slovenski jezik. Svojo biografijo Komenskega je zaključil takole: „Večna slava slavnemu slovanskemu pedagogu J. A. Komenskemu!« (Ravnikar 1892, 98) - In tudi slednje ni ušlo pozornim Mahničevim očem in njegovemu srdu.

Med drugimi objavami zbuja pozornost prva, Tristoletnica J. A. Komenskega (Učiteljski tovariš 1892, št. 2, 17), ki v Komenskem prepoznava "najslavnejšega pedagoga slovanskega rodu«, najavlja, da je odbor Slovenskega učiteljskega društva sklenil za 19. aprila prirediti slovesnost $\mathrm{z}$ velikim koncertom, predvsem pa s posebnim pozivom vzpostavlja identitetno povezavo med slavljenjem Komenskega in identiteto slovenskega učitelja ter člana društva:

Drage koleginje in kolegi! Pokažimo tu javno, kaj naš stan premore! Pokažimo s številčno udeležbo, da enotno postopamo! Povzdignimo s takim postopanjem [prisotnost na slavnosti Komenskega in sodelovanje v pevskem zboru, dodal J. V] ugled učiteljskega stanu! (Učiteljski tovariš 1892, n. m.)

Ob njej velja omeniti tudi objavo dveh verzifikacij, od katerih je bila Ob tristoletnici rojstva Jana Amosa Komenskega javno recitirana na bésedi 19. aprila v ljubljanski čitalnici, druga, ki je naslovljena s Slava Komenskemu in je prišla izpod rok Dragotina Jesenka - Doksova (18641902), enega tistih "manjših" slovenskih pesnikov, ki so se v senci neprimerno zmožnejših literarnih ustvarjalcev ob koncu dolgega stoletja »meščanov in revolucij« posušili na literarnem obrobju - Jesenko je 


\section{Slava Komenskemu}

Evropa se pripravlja

Na slavje prekrasnó,

Z njo širni svet proslavlja

Komenskega imé s častjó,

Imé nesmrtnega možá,

Možá orjaškega duhá.

Da, bil si velikán

Modrôsti, učenôsti,

A i srcá krepôsti

Iskrenovdan.

Vse te slavi,

Vse te slavi!

In če proslavlja Te tujina,

Če ves uklanja se Ti svet,

Bi-li ne čislala Te domovina,

Ki nje najdičnejši si cvet?

Slavi Te, ž njo pa Tvoj častiti god

Vesel praznuje i naš rod,

Razvnet se čuje po Slovenskem

Spev o Komenskem,

Uzorni odličnjak,

Tu dúševni orjak,

Ki z ženijalnostjo si duhovito,

$\mathrm{Z}$ marljivostjo prečudovito

Začrtal pot nam nov,

Po kterem je hoditi:

Kakó je vzgájati mladino

Za Bôga, vero, domovino,

Kakó z uspehom jo učiti,

Kakó ji dober oča biti,

Navodov zlatih zlatih nam podaril,

Vse šolstvo si prestvaril,
Pouku, vzgoji temelj dal si

Učitelj vseh rodóv,

Spasitelj iz duhá okov!

Globoke misli zasnovali si,

Globoke misli,

Ves svet jih ima v čisli.

A mi najbolj Te počastímo,

Da skušamo nasledniki Ti biti vredni

In v ukaželjnosti dosledni,

Po vedi bolj in bolj še hrepenimo,

Po vedi,

Ki so učil jo v pismi in besedi,

Po njej, ki Ti prešinola je bitje,

Ki zanjo dal si žitje,

Ti dúševni orjak,

Častiti naš očak!

A dási základe tolike

Duhá si v sebi združeval,

Da luč so zvali Te omike

Ponižen si ostal,

Krasán zgled skrômnosti

Potômnosti.

Uzor Ti ljubeznivosti

In moške nevpogljivosti!

V kulture knjige boš v spomini

Nikdár venočem žil,

$\mathrm{Z}$ najvrednejšimi vede sini

Ti čas bo vence slave vil

Tu dúševni orjak,

Častiti naš očak!

Tvoj duh med nami plava,

Na vekomaj Ti: Slava!

(Jesenko 1892, 114) 
zadnje obdobje življenja pesnil predvsem o opoju, ki ga je najraje užival, o vinu -, pa ob pozornem branju razkriva navdušeno čustveno ozračje proslav Komenskega v jubilejnem letu in morda celo izvajalsko prakso pri petju zgoraj omenjenega Ipavčevega moškega zbora $v$ čast znamenitega učenjaka.

Tod in drugje zapisanih izrazov slavljenja, čeprav le prigodniškega, Mahnič ni ne mogel ne hotel spregledati: slava pritiče le Odrešeniku in ljubemu Bogu, tod pa da se po učiteljskih časopisih nedostojno poveličuje češkega krivoverca. Kot sicer je njegov slog v obeh esejih, ki se zdita na prvi pogled posvečena Komenskemu, zagotovo eden najbolj dinamičnih, živopisnih, edinstvenih in retorično prepričljivih esejističnih stilov slovenskega peresa iz obdobja fin-de-siècla: ob slovenskem in evropskem, tudi klasičnem literarnem kanonu vzgojeni bralec bo težko prezrl prefinjene skladenjske konstrukcije in na kar največji recepcijski učinek naravnano rabo tropov in figur, zlasti antitetičnosti in hiperbole. Zato so tovrstni spisi goriškega teologa vse prej kot nesugestivni, vplivajo zlasti $\mathrm{z}$ retoričnim pathosom, $\mathrm{z}$ vnemo in strastjo apostola, s katero Mahnič nikogar, celo najbolj odločnega ideološkega nasprotnika ne pusti hladnega, $v$ svojih topoglednih besedilih pa se kaže kot izjemen poznavalec bralstva, za katerega piše, njegovih mentalnih obzorij in horizonta pričakovanja. Nagonsko ali zavoljo premisleka ve, na katero struno in kako zaigrati: česa si njegovi poglavitni recipienti želijo, kaj so pripravljeni sprejeti in česa ne, česa se bojijo in kaj jim prija. In zna ta občutja tudi ubesediti skozi mentalne horizonte trojice zbirnih pojmov: Bog/krščanstvo, kot ju tolmači Rimska cerkev; vera = Rimska cerkev; cesar. Ter izpeljati in zapisati na videz neizogibne miselne posledice za polje kateregakoli družbenega podsistema.

Tako je npr. s svojim doslednim, toda do drugega in drugačnega neprizanesljivim rimskokatoliško idealističnim estetskim pogledom tehtal slovensko književnost 19. stoletja oziroma se vključil v »boj o 
najvišjih načelih, od katerih je končno odvisen ves duševni razvoj človeštva« (Mahnič 1887, 3). Pri tem je strogo pretresal umetnostne tokove, npr. naturalizem, pa tudi svoje sodobnike, Stritarja in njegov (Dunajski) Zvon, Gregorčiča, Celestina ter posebej žolčno Aškrca, in celo tiste avtorje, ki za svojo ustvarjalnost sami niso mogli več zastaviti lastne besede, ker so bili že pokojni. Tak slovenski umetnik je bil tedaj France Prešeren, pri katerem potegne Mahnič enačaj med pesnikovim zasebnim ljubezenskim življenjem, ki ga tehta $z$ utežmi tradicionalne katoliške moralke, in ljubezensko tematiko v Prešernovih poezijah. Mahnič zapiše:

Sodba ni težka. Prešeren je ljuboval pred časom, brez pravega namena, brez zakona, zatorej je ljubezen njegova protinaravna, pregrešna. In ker je ta ljubezen $\mathrm{v}$ pesmih njegovih upodobljena v najlepši čarobni obliki, rečemo lahko: Prešeren nam v zlati, umeteljno izdelani posodi podaja strup pregrešne strasti. Oblika je tako dovršena in čarobna, da se ušesu glasi kako nebeška harmonija, se polasti čutov, vname kri in omami duha: zatorej se je mislilo nekdaj, kdor hoče brati Prešerna, bodi trezen, um njegov imej v oblasti domišljijo, bodi že izkušen, prileten, da pozna življenje in ljubezen pravo in pregrešno v vseh njenih posledicah. Mladina pa neizkušena, vroče krvi, bujne, neukrotne domišljije, lahkoverna, pusti Prešerna, da omamljena od njegove zapeljive lire se ti ne vname v srcu ogenj strasti, katera pred časom popari in spodje tvoje duševne in telesne moči in te spravi v zgodnji grob. [...] Prešeren je bil ubog, nesrečen človek, v katerem je divja strast zmogla nad razumom in ga podjarmila, bil je torej eden tistih, kakršne večkrat med grešnimi ljudmi nahajamo. Zatorej pa ga nikakor nočemo obsoditi, temveč pomilujemo ga in prosimo: Bodi mu Bog milostljiv. Pomilujemo ga tem več, vide, kako je svojo res nenavadno pesniško nadarjenost, kakršne še noben Slovenec ni imel, večkrat zlorabil in se valjal po blatu polt[en]osti in pregrešne ljubezni, vide, kako je svoje darove v najlepšem cvetu moške starosti zapravil in pogreznil se v prerani grob. Velik nam je Prešeren ... občudovanja vreden, pa še mnogo, mnogo večji bi bil, da bi bil čistega mišljenja in da bi ne bil te velikosti omadeževal s pregrešno strastjo. (Mahnič 1887, 155-56) 
Tudi v zvezi s Komenským ima podoben miselni postop. Pravzaprav ne učenjakova učenost in ne njegovi številni temeljni teksti pri Mahniču ne pretehtajo. Celo »občečloveška veljavnost « in da je »velikan učenosti, očak učiteljev ( Mahnič 1892a, 66, 65), kar Mahnič Komenskemu brez težave pripozna, ne. Mahnič namreč čuti potrebo, da se razgovori o lastnih verskih in domoljubnih pomislekih zoper slavljenje Komenskega, kajti možak vendar ni katoličan. S Komenským je celo še huje: Mahnič ne pozabi ves čas pribijati, da je znameniti učenjak nekatoličan, češki brat, »husit«, kot ga imenuje. - Heretik. Zato more biti vse, kar prihaja od njega in se na prvi pogled zdi dobro, le privid. In slednjega da je ne le mogoče, temveč ga je za potrebe šolnikov, ki da ne dovolj poučeni v Popotniku in Učiteljskem tovarišu pojejo Komensku neumestno hvalo in vzklikajo slavo - po Mahničevem ravno zato, ker niso dovolj razgledani -, celo nujno razkrinkati in prikazati takšnega, kot in kar v resnici po Mahničevem je. Ali kot antidobro, torej zlo, kajti Komenskega teološke, filozofske in panzofske ideje ter koncepti (npr. enaka obravnava otrok vseh stanov in obeh spolov v pedagoškem procesu) naj bi po Mahničevem mnenju predstavljali kar same temelje od katoliškega teologa najbolj ožigosanih pojavov njegove dobe - od prostozidarstva do socializma in celo - komunizma. Ali kot nekaj, kar je pravzaprav zraslo na jezuitskem intelektualnem vrtu, pa se zdaj Komenskemu neumestno pripisuje intelektualno prvenstvo. Ali kot nekaj, kar je v opreki z učiteljsko avtoriteto Rimske cerkve (»subjektivizem v verskih vprašanjih«). Vsota za češkega učenjaka pri Mahniču nikakor ne more biti pozitivna in tako učeni goriški teolog lahko vzpostavi navidezni argumentativni temelj za sklep, da naj bi tudi slovenski šolniki pokazali več previdnosti v zvezi z blagopokojnim Čehom, predvsem pa naj slednjega ne bi častili.

Komenskega šteje Mahnič za "apostola masonstva« in zapiše:

Da, tako je: Komenský je veliki apostelj modernega ložinega framasonstva. [H]očemo točko za točko iz Komenskega spisov dokazati, da je on $\mathrm{v}$ načelu vse učil, kar masonstvo izpoveduje in dejansko izvršuje. Iz tega pa naj se tudi sprevidi, kam pravzaprav pelje »neomejeno « češčenje češkega pedagoga - Komenskega. (Mahnič 1892a, 72) 
In nadaljuje:

Po pravici tedaj vprašamo: kaj pač izpovedujejo, kaj visoko čislajo masoni, kar bi se ali očitno ali skrito ne nahajalo v brezštevilnih delih Komenskega? Masoni obsojajo vojsko kot nezakonito - Komenský jo isto tako preklinja kot slabo, v katerikoli namen bi se imeli ljudje vojskovati. V socialnem življenju težijo masoni po izenačenju vseh ljudi in stanov, njih ideal je skrajna demokracija in komunizem. In tudi v tem je njih učitelj Komenský, kateri v svojih spisih kaže povsod na apostolsko dobo prvih kristjanov, češ, po onem idealu bi tudi med sedanjimi kristjani ne smelo biti nikake razlike niti v imetju, niti po stanu, niti po narodnosti. Vsi enaki! - edina dostojnost, katera pristoji vsem brez razlike, se izraža v nazivu »kristjan«! In ker se »kristjan« istoveti s »človekom - evo vam v Komenskega nazorih seme poznejšega socializma in komunizma [poudaril J. V.]! (Mahnič 1892a, 77)

V povzetku: mednarodne slovesnosti Komenskega 1892. so delo princev teme iz templjev prostozidarskih lož, in sicer zato, da se dela negativna propaganda zoper Rimsko cerkev (Mahnič 1892a, 67), pedagogika Komenskega ali ni izvirna (Mahnič 1892b, 138) ali pa vzgaja učečo se mladino k slabemu, npr. k sovraštvu do habsburške vladarske hiše in monarhije (Mahnič 1892a, 69), nekatoliško krščanstvo Komenskega in noben njegovih miselnih konceptov ni pripusten, ker so vsi heretični, ker spodbujajo k aktivnemu krščanstvu ter ljubezni vseh in vsakogar (Mahnič je imel v svojem pisanju resne zagate tudi s tem, kako bi katoličan krščansko ljubezen in enakovrednost izkazal muslimanu), ker je v njih najti temelj vsega zla v evropski kulturi - izenačujoči pogled na ljudi in stanove (slednje se je na račun meščanov v Habsburški monarhiji v resnici zgodilo $\mathrm{z}$ uvedbo splošne moške volilne pravice, ki ni bila vezana na davčni cenzus) - ter tako masonstva, socializma in celo - komunizma.

Mahnič je tako o Komenskem zatrdil:

Ono, po čemer se katolištvo bistveno razlikuje od akatolištva, je princip cerkvene avtoritete: katoličani smo le, v kolikor [vse poudarki kot v iz- 
virniku] verujemo in ker verujemo, kar nas sv. cerkev uči. Principu avtoritete heretiki nasproti postavljajo neomejeno prostost subjektivnega naziranja $v$ verskih rečeh. In ta je tudi princip, katerega se drži loža: on prepušča vsakemu, naj misli o Bogu in verskih rečeh, kakor mu je ljubo. Seveda samo katoliško ne! Upor proti učeči cerkveni avtoriteti ter neomejena prostost subjektivnosti je tudi v husitstvu glavni znak. Ni res, da je Luter prvi proglasil princip subjektivizma za najvišji v verskih vprašanjih: to je pred njim storil že Hus, a za Husom je kot dedič njegovega duha Komenský ta princip dalje razvil; Hus in Komenský sta nerazdružljiva. (Mahnič 1892b, 72-73)

In tudi:

[B]rezmiselno [je] ločevati med Komenským kot heretikom in pedagogom, ker vera zavzema celega človeka in določa vse njegovo mišljenje in delovanje, torej tudi, v koliko se razteza na vzgojo; da, nikjer versko naziranje globlje ne sega kot ravno pri vzgoji. Predmet vzgoje je namreč človek; ravno vera je pa, ki določa vprašanja v razmerju do najvišjega bitja, o končnem smotru, kakor tudi o smotru sedanjega življenja. Kakor odgovarja vera na ta vprašanja, tako in po tem se bo ravnala tudi vzgoja človekova. Naravna, da drugače bo hotel vzgajati svojega otroka darvinist, drugače mohamedanec, drugače racionalist, a drugače katoličan! In tako tudi vzgoja, izvršena po nazorih Komenskega-pedagoga [poudarjeno v izvirni$\mathrm{ku}$, se ne more in se ne da tako izvršiti, da ne bi se pokorila tudi nazorom Komenskega - heretika (Mahnič 1892b, 139)

Mahničev katoliški ekskluzivizem in njegova miselna pozicija aut aut nista bila v njegovem času v slovenski kulturi nič prav posebnega in nista definirala izključno Mahničevega idearija in imaginarija. Na katoliški strani jo je namreč brez težave prebrati v besedilih, ki takrat na-

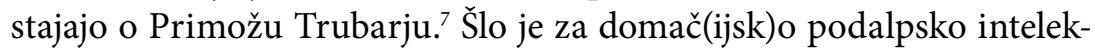
tualnozgodovinsko aplikacijo znamenitega Ciprijanovega izreka Nulla salus extra Ecclesiam. Josip Valentin Gruden tako kot sklep svojega zgo-

7 Več je prebrati $\mathrm{v}$ razpravi Nenada Vitorovića o polemiki ob štiristoletnici Trubarjevega rojstva (Vitorović 2006, 217-63). 
dovinopisnega narativa o Primožu Trubarju v Zgodovini slovenskega naroda konstatira:

Ako se ob sklepu še enkrat ozremo na Trubarjev značaj in njegovo delovanje, moramo reči: Mogočni valovi velikega verskega gibanja so Trubarja mnogo višje dvignili, kakor bi se bil sicer mogel povzpeti s svojimi lastnimi močmi. Bil je mož srednje naobrazbe, brez izrednih darov uma in srca. [...]

V svojem cerkvenem delovanju je bil popolnoma odvisen od virtemberških bogoslovcev, ki so mu dajali pravec, in od kranjskih stanov, katerih "ponižni sluga« je bil. Zato našemu verskemu gibanju ni vtisnil pečata svoje osebnosti. Kot pisatelj Trubar ni bil samostojen in originalen. Vsa njegova dela so skoraj izključno prevodi nemških protestantskih knjig. (Gruden 1912, 656).

Josip Lavtižar pa svojega Primoža Trubarja, versko sliko našega naroda iz 16. stoletja, delo, ki je, kot je misliti, ciljalo na najbolj splošnega bralca, končuje s pomenljivim stavkom. Ta bi mogel biti pravzaprav moto tovrstnega rimskokatoliškega integralističnega dojemanja, kot je uokvirjalo tako recepcijo Komenskega kot slovenske reformacije ob kon$\mathrm{cu}$ 19. stoletja pa vse tja do druge svetovne vojne:

Primož Trubar! Čast si delal materini besedi. Žal, da nisi delal časti tudi njeni veri. (Lavtižar 1935, 128)

Toda: v obeh Mahničevih esejih o Komenskem se v zvezi z znamenitim češkim učenjakom ves čas prepletajo trije narativi. Brati je namreč tisto, 1) kar je Komenský zapisal sam in je Mahnič večinoma brez sklicevanja na konkretna mesta v izvirniku prepisal v svoji besedili, ob tem 2) vrednotenje Komenskega v očeh Mahniča in nazadnje številne odmeve 3) narativa o Komenskem, kot ga je v biografiji o njem zapisal znameniti češki pedagog, psiholog, sociolog in filozof odločno liberalnih nazorov Gustav Adolf Lindner (1828-1887), ki ga češka kulturna zgodovina šteje za najpomembnejšega pedagoga po Komenskem. Dominantna sta zlasti Mahničevo vrednotenje Komenskega in topogledno utemeljevanje in 
polemiziranje v prvi vrsti z Lindnerjevim delom, pri čemer Komenský kot primarna snov stopa $\mathrm{v}$ ozadje, $\mathrm{v}$ prvi plan pa se prebija vprašanje: Kaj naj počne moderna šola? Naj vzgaja »državljane nebes«, kot je želel z evokacijo Didactice magne poudariti Mahnič, ali pa naj upošteva Lindnerjev pedagoški nazor, ki si ga je izoblikoval pod vplivom nemškega filozofa, psihologa in pedagoga Johanna Friedricha Herbarta (17761841), da je šola s svojimi pedagoškimi pristopi orodje za izboljševanje tostranskega življenja - družbe.

Spoprijem med Mahničem in slovenskimi šolniki o Lindnerjevi pedagogiki ter njeni recepciji med Slovenci v letu Komenskega ni bil popolna novost, temveč je imel brado že iz leta 1890, Komenský pa je dve leti kasneje bojevitemu goriškemu teologu, kot se zdi, služil predvsem kot priročno strelivo za nek drugo, znatno pomenljivejše idejno razčiščevanje.

Toda o sporu o »Lindnerjevem krščanstvu«, njegovem ideariju, imaginariju in pedagogiki na obeh straneh - Mahničevi in liberalnih šolnikov okoli Popotnika -, zlasti pa o zavojih, vijugah, stranpoteh in mrtvih rokavih, ki so recepcijo češkega učenjaka zaznamovali v stoletju skrajnosti, poglavitno v slabega pol stoletja poklicnih inženirjev duš in ustvarjalcev »novega človeka" (1945-1991), ter odmevajo celo v najsodobnejši slovenski recepciji Komenskega, more beseda teči $\mathrm{v}$ nadaljevanju pričujoče razprave $\mathrm{v}$ kateri od prihodnjih številk pričujoče revije.

\section{VIRI IN LITERATURA}

Viri

Koniáš, Matěj Antonín. 1729. Clavis haeresim claudens et aperiens - Klíc kacírské bludy $k$ rozeznávání otvírající, $k$ vykořenění zamykající. Hradec Králové: v Wáclawa Jana Tybély. http://www.digitalniknihovna.cz/mzk/uuid/ uuid:60827d7a-04do-48ca-8a5a-eeac60569a6d

Jesenko, Dragotin. 1892. "Slava Komenskemu.« Učiteljski tovariš XXXII: 114.

Mahnič, Anton. 1892a. »Internacijonalna slavnost Jana Amosa Komenskega.« Rimski katolik IV (2): 65-78.

- - -. 1892b. »Bodi luč! - slaviteljem Komenskega!« Rimski katolik IV (3): 136-47. 
Popotnik XII-XIII (1890-1892).

Učiteljski tovariš XXXII (1892).

\section{Literatura}

Gruden, Josip Valentin. 1912. Zgodovina slovenskega naroda. Celovec: Družba sv. Mohorja v Celovcu.

Hojan, Tatjana. 2003. »Popotnik.«V Slovenska kronika 19. stoletja II (1861-1883), ur. Janez Cvirn idr, 338. Ljubljana: Nova revija.

Lapajne, Ivan. 1877. "Šolske novice in drobtinice.«Slovenski učitelj V (23): 356-57.

Lavtižar, Josip. 1935. Primož Trubar, verska slika našega naroda iz 16. stoletja. Reteče-Planica na Gorenjskem: samozaložba.

Mahnič, Anton. 1887. Dvanajst večerov: pogovori doktorja Junija z mladim prijateljem. Gorica: Hilarijanska tiskarna.

Medveš, Zdenko. 1997. »Zakaj Komenski med Slovenci velja le za pedagoga?« Anthropos 29 (1-3): 67-71.

Pogačnik, Jože. 1968. Zgodovina slovenskega slovstva 1: srednji vek, reformacija in protireformacija, manirizem in barok. Maribor: Založba Obzorja.

Ravnikar, Jernej. 1892. »Jan Amos Komenski (V spomin tristoletnice).«Učiteljski tovariš XXXII: 33-36, 51-53, 65-67, 81-82, 97-98.

Valenčič, Vlado. 1989. Zgodovina ljubljanskih uličnih imen. Ljubljana: Partizanska knjiga, Zgodovinski arhiv Ljubljana.

Vinkler, Jonatan. 2010. »Medkulturni dialog 'Evropske komisije kot nova verska toleranca in patent Jožefa II., imenovan ,tolerančni'" "Šlsko polje, revija za teorijo in raziskave vzgoje in izobraževanja XXI (5-6): 27-97.

Vitorović, Nenad Hardi. 2006. »Protestantizem v polemikah ob štiristo letnici Trubarjevega rojstva.«V Protestantizem, slovenska indentiteta in združujoča se Evro$p a$, ur. Marko Kerševan, 217-63. Ljubljana: Znanstvenoraziskovalni inštitut Filozofske fakultete.

Walter, Monika. 2002. »Besedje v slovenskih prevodih Sveta v slikah J. A. Komenskega.« Diplomsko delo, Univerza v Ljubljani. 